\title{
Vasectomy: a study of attitudes, beliefs, knowledge and practices among literate men in Punjab, India
}

\author{
Aditya Sood*, Parika Pahwa
}

State Institute of Health and Family Welfare, Government of Punjab, Phase 6, Mohali, Punjab, India

Received: 5 May 2014

Accepted: 23 May 2014

\section{*Correspondence:}

Dr. Aditya Sood,

E-mail: aditya.adi108@gmail.com

(C) 2014 Sood A et al. This is an open-access article distributed under the terms of the Creative Commons Attribution Non-Commercial License, which permits unrestricted non-commercial use, distribution, and reproduction in any medium, provided the original work is properly cited.

\begin{abstract}
Background: Government launched the family planning program in India almost six decades back; further to that cause, it introduced non scalpel vasectomy to the public in 1992 aimed at male sterilization but despite of all the monetary incentives, IEC \& BCC campaigns and increase in literacy rate, vasectomy still accounts for only 1 percent of all the family planning methods used across the nation. In Punjab, the coverage is just $0.6 \%$ and therefore this study was conducted to understand the attitude, knowledge, beliefs and myths amongst the participants in relation with vasectomy.

Methods: A cross sectional descriptive study was carried out in three districts of Punjab. Literate married and unmarried men of age group 18-60 years with education qualification above $10^{\text {th }}$ standard were included in the study. A total of 225 males, 75 from each district irrespective of caste, religion or socioeconomic status were selected by random sampling method.

Results: $70 \%$ respondents had heard about vasectomy. $42 \%$ accepted it as a male contraceptive method but only $11 \%$ said that they would like to undergo the procedure in future. The primary reason cited for not undergoing vasectomy was that 53\% men believed that tubectomy was a simpler procedure therefore their partners should undergo sterilization instead. $52 \%$ feared failure of the procedure and the bad name it would bring to the family; if partner gets pregnant.

Conclusions: Government's IEC and BCC activities should focus more on addressing the myths and fears of men; related to vasectomy.
\end{abstract}

Keywords: Vasectomy, Attitude, Beliefs, Male, Sterilization

\section{INTRODUCTION}

India was the first country to introduce a national family planning programme in year 1952 with the main objective to reduce the growth rate so as to stabilize the population at a level consistent with the needs and potential of national economy. Over the years the range of contraceptive products provided through the programme has widened and many other services like immunization, antenatal care, postnatal care, pregnancy, delivery care, preventive and curative health services were also included and ultimately the programme was integrated with reproductive and child health programme. ${ }^{1}$ Non scalpel Vasectomy technique was introduced in India in 1992 to increase the male participation in family planning methods. ${ }^{2}$ Increased use of temporary contraceptives have been reported in India but the use of permanent contraception is very low. According to NFHS 3, the current acceptance of NSV in India has declined from 1.9 percent to 1 percent $^{3}$ and as per DLHS 3 Punjab, coverage of vasectomy is only 0.6 per cent. Also there is a magnanimous difference between the number of permanent sterilization cases (male and female). There are 42 times more female sterilizations taking place than male sterilizations. In recent years, the governments of India and of Punjab have taken steps to 
increase rates of male sterilization. In 2007, the ministry of health increased the amount of compensation for wages lost offered to vasectomy acceptors to Rs. 1100 for operations performed in the public sector. Punjab state government is spending Rs. 1500 per case for vasectomy; still vasectomy is highly underutilized due to an intrinsic unpopularity of the method. NSV after even being a simple and safe method has failed to achieve its goal. ${ }^{4}$ Thus the questionnaire based study was done to get insight of the men about their knowledge and attitude towards various contraceptives methods especially vasectomy and understanding some of the factors influencing the vasectomy acceptance as a contraceptive method.

\section{METHODS}

A cross sectional descriptive study was carried out in three districts of Punjab namely Ludhiana, Ferozepur and Mohali in the month of April and May 2012. The relevance of choosing these 3 districts was that Ludhiana is the most populous city of Punjab with good literacy rate and economic development, Mohali is situated at the periphery of State Capital i.e. Chandigarh which has access to all the health facilities and Ferozepur is the border city located at international border with Pakistan. Literate married and unmarried men of age group 18-60 years and education qualification above $10^{\text {th }}$ standard were included in the study. A total of 225 males, 75 from each district irrespective of caste, religion or socioeconomic status were selected by random sampling method. All the participants were clearly explained the purpose of the study and signed written consent form was taken from them. The pretested self-administered semi structured questionnaire was used for collection of data. For collecting the data, private and government banks, corporate offices, private companies, government offices, schools, and BPO's of these districts were targeted and selected randomly. Respondents were asked about their socioeconomic\& demographic profile; awareness of different family planning methods, attitude of respondents towards vasectomy, reasons of apprehension against adopting vasectomy and association of various socio demographic factors with vasectomy acceptance. A maximum of three visits were made at places before the required sample size was obtained. Data analysis was done with the help of excel \& SPSS 16. The data was tabulated in terms of frequency distribution of different variables. Chi-square test of significance was employed for testing associations. $\mathrm{P}<0.05$ was considered for statistical significance.

\section{RESULTS}

\section{Section A: socio-demographic profile}

Table 1 shows that majority of the respondents (44\%) interviewed were in the age group of $31-45$ years, $40 \%$ of them were graduates $\&$ post graduates respectively while $67.6 \%$ were Hindu by religion.
Table 1: Socioeconomic and demographic profile $(\mathrm{N}=225)$.

\begin{tabular}{|lll|}
\hline \multicolumn{2}{|l|}{ Number } & Percentage \\
\hline Age of respondents & & \\
\hline $18-30$ & 76 & 33.8 \\
\hline $31-45$ & 99 & 44.0 \\
\hline $46-60$ & 28 & 12.4 \\
\hline No Response & 22 & 9.8 \\
\hline Educational status & & \\
\hline Till 10 & \\
\hline Till 12 $2^{\text {th }}$ standard & 16 & 7.0 \\
\hline Graduate & 29 & 12.9 \\
\hline Post Graduate & 90 & 40 \\
\hline Religion & 90 & 40 \\
\hline Hindu & & \\
\hline Muslim & 152 & 67.6 \\
\hline Sikh & 02 & 0.9 \\
\hline Others & 54 & 24.0 \\
\hline No Response & 13 & 05.8 \\
\hline Category/Caste & & 01.8 \\
\hline SC/ST & 24 & 10.66 \\
\hline BC & 13 & 05.77 \\
\hline OBC & 07 & 03.11 \\
\hline General & 179 & 79.55 \\
\hline Others & 02 & 00.88 \\
\hline Annual Income & & \\
\hline None & 04 & 1.8 \\
\hline Less than 1 lakh & 19 & 8.4 \\
\hline 1 lakh to 3 lakh & 66 & 29.3 \\
\hline 3 lakh to 5 lakh & 81 & 36 \\
\hline More than 5 lakh & 55 & 24.4 \\
\hline Occupational status & & \\
\hline Unemployed & 04 & 1.8 \\
\hline Government service & 83 & 36.9 \\
\hline Private service & 81 & 36.0 \\
\hline Business & \\
\hline Student & \\
\hline Others & \\
\hline No Response & \\
\hline
\end{tabular}

Table 2: Most of the study participants (68\%) were married at the time of interview. Another $27 \%$ were single/never married, and the rest were either divorced/separated or widowed. Educational level of spouses was found to be good, $35 \%$ graduates and $24 \%$ post-graduates. Out of the 153 married men, 56\% have been married for more than 10 years, $20 \%$ for 5 to 10 years and the rest for less than 5 years.

Data presented in the Table 3 reveals that condom was the most widely known method of contraception .A majority of respondents i.e. 213 (95\%) knew about it, followed by withdrawal $(84 \%)$, emergency contraceptive pills $(81 \%)$, and tubectomy $(79 \%)$ respectively. 
Table 2: Information related to marriage and spouse.

\begin{tabular}{|c|c|c|}
\hline & Number & Percentage \\
\hline \multicolumn{3}{|c|}{ Marital status of respondents $(\mathrm{N}=\mathbf{2 2 0})$} \\
\hline Never married & 60 & 27.27 \\
\hline Currently married & 153 & 69.54 \\
\hline Separated/ Divorced & 06 & 02.72 \\
\hline Widowed & 01 & 0.45 \\
\hline \multicolumn{3}{|c|}{ Qualification of spouse $(\mathrm{N}=153)$} \\
\hline Illetrate & 16 & 10.45 \\
\hline Till $10^{\text {th }}$ class & 17 & 11.11 \\
\hline Till $12^{\text {th }}$ class & 30 & 19.60 \\
\hline Graduation & 54 & 35.29 \\
\hline Post-graduation & 37 & 24.18 \\
\hline \multicolumn{3}{|c|}{ Years of marriage $(\mathrm{N}=153)$} \\
\hline Less than 1 year & 09 & 05.88 \\
\hline 1 to 5 years & 28 & 18.30 \\
\hline 5 to 10 years & 30 & 19.60 \\
\hline More than 10 years & 86 & 56.20 \\
\hline
\end{tabular}

Table 3: Awareness of different family planning methods $(\mathrm{N}=\mathbf{2 2 5})$.

\begin{tabular}{|lll|}
\hline Method & Number & Percentage \\
\hline Condoms & 213 & 95 \\
\hline Emergency contraceptive pills & 182 & 81 \\
\hline Oral contraceptive pills & 174 & 78 \\
\hline Copper T & 106 & 47 \\
\hline Vasectomy & 156 & 70 \\
\hline Tubectomy & 178 & 79 \\
\hline Safe periods & 156 & 70 \\
\hline Withdrawl & 189 & 84 \\
\hline Injectables & 84 & 37 \\
\hline Others & 07 & 03 \\
\hline
\end{tabular}

Table 4 indicates that newspapers are the major source of information $(67 \%)$ on contraception for our respondents, followed by magazines and television advertisements at $48 \%$ and $51 \%$ respectively.

Table 4: Source of awareness of contraceptive methods $(\mathrm{N}=\mathbf{2 2 5})$.

\begin{tabular}{|lll|}
\hline Medium & Number & Percentage \\
\hline Newspaper & 145 & 67 \\
\hline Magazines & 104 & 48 \\
\hline Advertisement on TV & 110 & 51 \\
\hline Internet & 75 & 35 \\
\hline Radio & 33 & 15 \\
\hline Friends/family & 61 & 28 \\
\hline Health/medical professionals & 70 & 32 \\
\hline
\end{tabular}

\section{Section B: vasectomy}

Table 5 helps to clarify the respondent's knowledge and attitude on vasectomy. It can be seen that about $70 \%$ respondents have heard of vasectomy and male
Sterilization, while $27 \%$ had no clue of it and $4 \%$ did not respond to the question. Further, acceptance of Vasectomy as a male contraceptive method stands at $42 \%$. Only $11 \%$ respondents showed willingness to undergo vasectomy in future.

Table 5: Knowledge and attitude of respondents towards vasectomy.

\begin{tabular}{|llll|}
\hline & Yes & No & $\begin{array}{l}\text { No } \\
\text { response }\end{array}$ \\
\hline $\begin{array}{l}\text { Heard about } \\
\text { vasectomy/male } \\
\text { sterilization (n=225) }\end{array}$ & $156(70 \%)$ & $60(27 \%)$ & $9(4 \%)$ \\
\hline $\begin{array}{l}\text { Acceptance of } \\
\text { vasectomy as a male } \\
\text { contraceptive } \\
\text { method (n=225) }\end{array}$ & $95(42 \%)$ & $130(58 \%)$ & 00 \\
\hline $\begin{array}{l}\text { Undergone } \\
\text { vasectomy (n=153) }\end{array}$ & $03(2 \%)$ & $150(98 \%)$ & 00 \\
\hline $\begin{array}{l}\text { Willingness to } \\
\text { undergo vasectomy } \\
\text { in future (n=156) }\end{array}$ & $23(11 \%)$ & $202(89 \%)$ & 00 \\
\hline $\begin{array}{l}\text { Vasectomy is better } \\
\text { method of } \\
\text { sterilization then } \\
\text { tubectomy (n=178) }\end{array}$ & $55(31 \%)$ & $53(30 \%)$ & $53(30 \%)$ \\
\hline
\end{tabular}

Table 6 puts light on the most important revelations' of this study and explains about various reasons which are believed to be attached and associated with the nonacceptance and under-utilization of Vasectomy as a male contraceptive method. As respondents were allowed to mark multiple options for this question, the result shows that almost half of them, i.e. $53 \%$ believe that, "Female sterilization has lesser side effects and is easier, so women should get sterilized; not men".

Table 6: Reasons for apprehension against adopting vasectomy $(\mathrm{N}=156)$.

\begin{tabular}{|l|ll|}
\hline Reasons & Number & Percentage \\
\hline $\begin{array}{l}\text { Being earning hand, cannot } \\
\text { take leave from work }\end{array}$ & 56 & 36 \\
\hline Vasectomy causes weakness & 09 & 06 \\
\hline It causes reduced work output & 13 & 08 \\
\hline Loss of libido & 08 & 05 \\
\hline $\begin{array}{l}\text { Fear of failure of vasectomy } \\
\text { as it brings bad name to wife }\end{array}$ & 81 & 52 \\
\hline $\begin{array}{l}\text { Females themselves wants to } \\
\text { undergo sterilization }\end{array}$ & 52 & 33 \\
\hline $\begin{array}{l}\text { Prefer to get female partner } \\
\text { sterilized (easier/ lesser side } \\
\text { effects) }\end{array}$ & 83 & 53 \\
\hline
\end{tabular}

$52 \%$ of the respondents revealed their fear of failure of the procedure and subsequent embarrassment and bad name that a pregnancy would bring to the woman and the family. $36 \%$ thought that they would have to be absent 
from work in order to get it done and rest later and being the earning hands they do not want to risk their jobs. 33\% said that they think women themselves want to undergo sterilization instead of putting their husband under the knife.

Table 7: Association between socio-demographic indicators and acceptance of vasectomy method.

\begin{tabular}{|c|c|c|c|}
\hline & \multicolumn{2}{|c|}{$\begin{array}{l}\text { Vasectomy acceptance } \\
(\mathrm{n}=225)\end{array}$} & \multirow[t]{2}{*}{ P value } \\
\hline & No & Yes & \\
\hline \multicolumn{4}{|c|}{ Age of the respondent $(n=203)$} \\
\hline $18-30$ years & $52(69 \%)$ & $24(31 \%)$ & \multirow{4}{*}{0.001} \\
\hline $31-45$ years & $45(46 \%)$ & $54(54 \%)$ & \\
\hline $46-60$ years & $22(79 \%)$ & $6(21 \%)$ & \\
\hline Total & $119(59 \%)$ & $84(41 \%)$ & \\
\hline \multicolumn{4}{|c|}{ Education $(n=225)$} \\
\hline Till $10^{\text {th }}$ standard & $6(38 \%)$ & $10(62 \%)$ & \multirow{5}{*}{0.007} \\
\hline Till $12^{\text {th }}$ standard & $11(38 \%)$ & $18(62 \%)$ & \\
\hline Graduate & $62(69 \%)$ & $28(31 \%)$ & \\
\hline Post-graduate & $51(57 \%)$ & $39(43 \%)$ & \\
\hline Total & $130(58 \%)$ & $95(42 \%)$ & \\
\hline \multicolumn{4}{|c|}{ Occupation $(n=213)$} \\
\hline Unemployed & $4(100 \%)$ & $0(0 \%)$ & \multirow{7}{*}{0.010} \\
\hline Govt. service & $36(43 \%)$ & $47(57 \%)$ & \\
\hline Private service & $52(64 \%)$ & $29(36 \%)$ & \\
\hline Businessman & $17(74 \%)$ & $6(26 \%)$ & \\
\hline Student & $6(75 \%)$ & $2(25 \%)$ & \\
\hline Others & $9(64 \%)$ & $5(36 \%)$ & \\
\hline Total & $124(58 \%)$ & $89(42 \%)$ & \\
\hline \multicolumn{4}{|c|}{ Annual income $(n=225)$} \\
\hline None & $3(75 \%)$ & $1(25 \%)$ & \multirow{6}{*}{0.313} \\
\hline Less than 1 lakh & $15(79 \%)$ & $4(21 \%)$ & \\
\hline 1 lakh to 3 lakh & $35(53 \%)$ & $31(47 \%)$ & \\
\hline 3 lakh to 5 lakh & $45(56 \%)$ & $36(44 \%)$ & \\
\hline More than 5 lakh & $32(58 \%)$ & $23(42 \%)$ & \\
\hline Total & $130(58 \%)$ & $95(42 \%)$ & \\
\hline
\end{tabular}

\section{DISCUSSION}

Population of India as per the 2011 census is 1.2 billion, it has shown an increase of 181 million during the decade $2001-2010^{5}$ though the decadal growth rate registered the sharpest decline since independence, a decrease of 3.9 points; from 21.54 to $17.64 .^{6}$ However, this decline does not undermine the importance of continued efforts to promote family planning measures ${ }^{4}$ and thereby Ministry of health and family welfare, government of India has been promoting family planning programmes in the country. There are number of contraceptive measures/products available under the purview of family planning and all the services are provided free of cost to the population through the public health facilities at the district, block and community levels. There is a strong emphasis on IEC and BCC activities in order to promote these measures. It is being done by the government itself and with the help of national and international NGOs, developmental partners etc. Despite of all the efforts, only 0.7 per cent urban and 1.0 per cent rural population uses vasectomy as a method of choice for contraception. ${ }^{7}$ In case of Punjab, the situation is no better, average coverage of vasectomy is only 0.6 per cent. ${ }^{7}$ This study was conducted in the state of Punjab with the objective to understand the attitude, acceptance and beliefs of males about vasectomy. Most of the study subjects showed fair to good knowledge about various contraceptive measures available in the market for males, it did not come as a surprise to the researchers as it was expected of them to be better informed as all of them were literates with more than half of them being at least graduates. More than $70 \%$ had heard about male/female sterilization, barrier and natural methods. The only two methods where their awareness was not up to the mark was in case of Intra uterine Devices and Injectables. When we compared these results to a study conducted by Garg et al. in a tertiary hospital of North India on healthy male attendants of admitted patients, it was found that in comparison to our respondents awareness of vasectomy (70\%) their respondents were more aware $(97.4 \%)$. Their source of information was mainly television and friends while printed advertisements (magazines, pamphlets, and posters) hardly contributed anything in spreading knowledge ${ }^{4}$ whereas in our case, friends\& family were not an active source of information for the respondents. This leads us to believe that mouth to mouth publicity of sterilization methods is not very effective in Punjab but newspapers and magazines are. It is further important to highlight the fact that only $48.0 \%$ of the respondents approve of male sterilization as a possible option of family planning however, only one fifth of them are willing to undergo vasectomy. This emphasizes the fact that there is a large gap in their knowledge about advantages of vasectomy which leads to reluctance to undergo vasectomy. A study by Ebeigbe et al. done on Nigerian resident gynecologists revealed that Nigerian males will not accept vasectomy because of hesitance towards counseling for vasectomy and greater willingness towards counseling couples with completed family sizes for bilateral tubal ligation. ${ }^{8}$ The findings of a previous study suggest that spread of accurate information among the population is a major contributor to better acceptance of vasectomy. ${ }^{9}$ It is possible that vasectomy's underutilization is due to an intrinsic unpopularity of the method. However, certain characteristics of vasectomy make it a potentially attractive option within the family planning menu. It is effective (on the individual and population levels), it is a simple procedure with few complications, and it is one of the few available "modern" methods that involve men directly. ${ }^{10}$

As discussed earlier, the main motive of the study was to understand the reasons that discourage even the most literate and affluent males from the society in Punjab to skip this option. It was found that the main concern of the men was that if they get it done and their partners conceives then it would bring a bad name to the woman as well as to the family. This was an astonishing 
revelation as none of the previously reported studies have ever cited this as one of the main reason for nonacceptance of vasectomy. The major reason earlier stated in other studies was the belief among men and women that vasectomy will lead to loss of libido, sexual power and may cause weakness to the men. ${ }^{11-13}$

This aspect was also highlighted in another survey where it was noted that "men would not tell other people if they had been sterilized, fearing being shamed and taunted by community members, who might refer to them using such words as Namard (meaning infertile). ${ }^{14}$

Some of the other reasons reported by the respondents were that women themselves prefer undergoing sterilization instead of getting their husbands sterilized; also some men tend to think that tubectomy is simpler, easier and less complicated than Vasectomy so they prefer to get their wives sterilized. The study also revealed that that rising education and income level does not have much to do with acceptance of vasectomy as well as with willingness to undergo the procedure in future.

\section{CONCLUSION}

In conclusion, ministry of health and family welfare, government of India needs to focus more on the negative beliefs and myths that men have for vasectomy. Promotional activities should aim to bridge the existing information gap among the potential audience/clients. A client satisfied with vasectomy may prove instrumental in convincing other persons to opt for vasectomy. This has been very aptly narrated by Dr. R.C.M. Kaza, NSV master trainer to the government of India as follows: "NSV is as much an IEC operation as a surgical operation". ${ }^{15}$ The IEC activities must deal with their apprehensions and should assure that most failures can be controlled by proper follow-up and instructions to the man undergoing the procedure. Men need to understand that they will not be infertile. ${ }^{16}$ To sum up, we would like to say that majority of men; whether educated or illiterate, rich or poor, belonging to any religion or region are afraid to get sterilized due to one or another reason. Therefore our efforts should be directed more towards eliminating and striking on their fear then to waste resources incentivizing and just popularizing the procedure.

\section{Funding: No funding sources}

Conflict of interest: None declared

Ethical approval: Not required

\section{REFERENCES}

1. KG Santhya. Changing family planning scenario in india: an overview of recent incidence. Population Council, New Delhi. 2003;17:1-44.

2. V. Kumar et al. An evaluation of the no-scalpel vasectomy technique. BJU Int. 1999;83(3):283-4.
3. National Fact Sheet India 2005-2006. National Family Health Survey 3 (NFHS-3) Ministry of Health and Family Welfare, Government of India. International institute for population studies, Mumbai, 2005-2006. Available at http://www.rchiips.org/NFHS/PDF/India.pdf.

4. Pankaj Kumar Garg et al. Non scalpel vasectomy as family planning method: a Battel yet to be conquered. Hindawi Publis Corp ISRN Urol. 2013 March;23:752174.

5. Census of India 2011, Ministry of Home affairs, Office of the Registrar General and Census Commissioner, India, 2011. Census data, population enumeration data, 2011. Available at: http://www.censusindia.gov.in/2011census/populatio n_enumeration.aspx.

6. Office of the Registrar General and Census Commissioner of India. Size, growth rate and distribution of population, 2011. Available at: http://www.censusindia.gov.in/2011-provresults/data files/india/ final PPT 2011 chapter3.pdf.

7. State Fact sheet 2007-2008. District level household \& facility survey (DLHS-3), 2007-2008. Available at: http://www.rchiips.org/state-fact-sheet-rch3.html.

8. P. N. Ebeigbei et al. Vasectomy: a survey of attitudes, counseling patterns and acceptance among Nigerian resident gynecologists. Ghana Med J. 2011 Sep;45(3):101-4.

9. Munhondwa $\mathrm{H}$ et al. Effect of Vasectomy promotion project on knowledge, attitudes and behavior among men in Dares Salaam, Tanzania. Population Council, Afr Operat Res Tech Ass Project, USAID. 1997 Sep;6:37.

10. Suzane L. Cohen. Vasectomy and national family planning programs in Asia and Latin America, 2013. Available at: http://cgi.unc.edu/uploads/media_items/vasectomyand-national-family-planning-programs-in-asia-andlatin-america.original.pdf

11. Escobar MC. An exploratory study on service providers' attitude towards vasectomy: Profamilia Clinics, Colombia. In: Escobar MC, eds. AVS. Bogota: AVS International; 1996.

12. Landrey E, Ward V. Perspectives from couples on the vasectomy decision: a six-country study. Reprod Health Matters. 1997;Special issue:58-67.

13. Zafer et al. Study of vasectomy adopters with special reference to motivational factors. Int J Sci Res Publications. 2013 Sep;3(9):1-6.

14. Beth Scott et al. Factors affecting acceptance of vasectomy in Uttar Pradesh: insight from community based, participatory qualitative research. In: Scott B, Alam D, Raman S, eds. The Respond Project Study Series: Contribution to Global Knowledge, USAID Report no 3. New York: EngenderHealth/The Respond Project; 2011: 1-77.

15. Frajzyngier V, Bunce A, et al. Factors affecting Vasectomy acceptability in the Kigoma region of Tanzania. In: Frajzyngier V, Bunce A, eds. The Acquire Project. E \& R Study No. 5. New York: 
USAID-Acquire Evaluation and Research Studies June; 2006: 1-28.

16. Ross JA, Hong $\mathrm{S}$ and Huber D. Voluntary sterilization: an international fact book. In: Ross JA, Hong $\mathrm{S}$ and Huber D, eds. International Fact Book.
New York: Association for voluntary Sterilization; 1985: 120.

DOI: $10.5455 / 2320-1770 . i j r c o g 20140627$

Cite this article as: Sood A, Pahwa P. Vasectomy: a study of attitudes, beliefs, knowledge and

practices among literate men in Punjab, India. Int J

Reprod Contracept Obstet Gynecol 2014;3:418-23. 